Check for updates

New Taipei City

Cite this as: BMJ 2022;376:0420 http://dx.doi.org/10.1136/bmj.0420 Published: 17 February 2022

\title{
Covid-19: China's president orders Hong Kong to control outbreak
}

\section{Andrew Silver}

China's President Xi Jinping has ordered Hong Kong to get a handle on its covid-19 epidemic amid a wave of newly confirmed cases in the special administrative region.

$\mathrm{Xi}$ said the "overriding mission” of Hong Kong's leaders was to stabilise and control an ongoing outbreak, media reported on16 February. ${ }^{1}$

There were over 4000 confirmed new cases of covid-19 in Hong Kong on 16 February, a new record, up from 600 cases on 10 February. But modelling released by Hong Kong University on 10 February $^{2}$ estimated there could be 28 ooo daily cases by the end of March, for the city with a population of 7.48 million.

China's central government has adopted a controversial "zero tolerance" approach to covid-19 outbreaks, which has sometimes led to containment measures for entire cities. ${ }^{3}$ But Hong Kong Chief Executive Carrie Lam, has ruled out a city wide lockdown, and some people believe it may not be possible to return to zero cases at this point.

The city does, however, plan to test the entire population for covid-19 three times over a three week period from next month, according to media reports, ${ }^{4}$ and will continue to use testing, contact tracing, and isolation to prevent and interrupt community transmission.

Last month, everyone with confirmed covid-19 in Hong Kong was required to go to hospital for quarantine and close contacts had to be isolated in designated facilities. Now, as cases surge, the hospital discharge criteria has loosened, allowing for shorter hospital stays, and close contacts can quarantine at home for 14 days after last exposure. The government has advised people with milder symptoms to wait at home until space is available at an isolation facility. It opened seven new clinics in the community for milder cases on 16 February. ${ }^{5}$

"The Hong Kong government will, in accordance with the important instruction of President Xi Jinping, assume the main responsibility to stabilise the epidemic situation early as the overriding mission at present, and mobilise all available manpower and resources, and adopt all necessary measures, to safeguard the lives and health of Hong Kong people and the stability of society," Lam said on 16 February.

She said that Hong Kong was getting assistance from China's central government to improve testing capacity and medical supplies, and construct community isolation and treatment facilities.

Omicron's transmissibility and ability to spread among people with mild or no symptoms makes controlling it particularly difficult. "Unfortunately, we had hidden cases, unknown cases that did transmit,” said Benjamin Cowling, an epidemiologist at Hong Kong University.

Estimated waiting time for one Kowloon emergency department was over eight hours on 16 February, according to the Hospital Authority website. ${ }^{6}$ AFP reported families were crammed into isolation tents outside another hospital the same night. ${ }^{7}$

"It was never so crowded at hospitals before in my memory," said Chan Pui Kwong, chairperson of the Hong Kong Doctors Union epidemics committee. "In the past 20 or 30 years there has never been such a situation."

Only $50.9 \%$ of people aged 70 to 79 and $22.5 \%$ of people 80 and above were fully vaccinated in Hong Kong as of 7 February. The Hong Kong Doctors Union has called for increasing vaccination uptake among students and senior residents. "We hope further to increase coverage so that our community can soon return to a greater sense of normalcy in life," it wrote in an open letter to the Hong Kong government on 12 February.

One of the challenges Hong Kong's authorities face in responding to covid-19 may be trust. "A large proportion of Hong Kong is distrustful of the government and doesn't think the government does anything for the people," one public health policy researcher at a university in Hong Kong told The BMJ under anonymity. "For the government to put up posters that say 'let's fight the virus together' is very hollow."

Kwok D, Master F. China's Xi sets Hong Kong's leaders “overriding mission” to control covid. Reuters. February 2022. www.reuters.com/world/asiapacific/chinas-xi-says-hong-kong-needs-stabilise-control-covid-surge-media2022-02-16.

2 Modelling the fifth wave of covid-19 in Hong Kong. February 2022. www.med.hku.hk/en/news/press/-/media/B0CCD4FE690A47B3990AE81268E185CB.ashx.

3 Silver A. Covid-19: Why China is sticking to "zero tolerance" public health measures. BMJ 2021;375doi: 10.1136/bmj.n2756.

4 unv.hk01.com/\%E6\%94\%BF\%E6\%83\%85/736691/01\%ET\%8D\%A8\%E5\%AE\%B6\%ЕВ

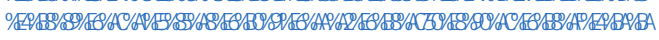

$5 \quad$ Heung S. Coronavirus Hong Kong: 7 clinics open as 12000 patients stuck at home waiting for hospital, quarantine admission. South China Morning Post. February 2022. www.scmp.com/news/hong-kong/health-environment/article/3167266/coronavirus-hong-kong-7-clinics-open-12000

6 Hospital Authority. A\&E waiting time. February 2022. www.ha.org.hk/visitor/ha_visitor_index.asp.

Battlefield mode": Hong Kong hospitals buckle under Omicron wave. February 2022. www.france24.com/en/live-news/20220217-battlefieldmode-hong-kong-hospitals-buckle-under-omicron-wave

This article is made freely available for personal use in accordance with BMJ's website terms and conditions for the duration of the covid-19 pandemic or unti otherwise determined by BMJ. You may download and print the article for any lawful, non-commercial purpose (including text and data mining) provided that all copyright notices and trade marks are retained. 